Ekonomica Sharia: Jurnal Pemikiran dan Pengembangan Ekonomi Syariah Volume 6 Nomor 1 Edisi Agustus 2020 | 61

\title{
GADAI DALAM ISLAM
}

\author{
${ }^{1}$ Choirunnisak, ${ }^{2}$ Disfa Lidian Handayani \\ ${ }^{1}$ Perbankan Syariah STEBIS IGM Palembang. Email: Choirunnisak-umar@stebisigm.ac.id \\ ${ }^{2}$ Fakultas Ekonomi Islam UIN Raden Fatah Palembang. \\ Email: disfalidian_uin@radenfatah.ac.id
}

\begin{abstract}
This research is a type of library research that focuses on qualitative data management with data analysis methods using descriptive analysis methods. Pawn in Islam is called Rahn. Islamic pawn shops will only benefit from the rental fees collected not in the form of interest or capital rents calculated from borrowed money.
\end{abstract}

Keywords: Pawn, Islam, Rahn.

\begin{abstract}
Abstrak
Penelitian ini merupakan penelitian jenis pustaka (library research) yang menitikberatkan pada pengelolaan data secara kualitatif dengan metode analisis data menggunakan metode deskriptif-analisis. Gadai dalam Islam disebut Rahn. Pegadaian Islam akan memperoleh keuntungan hanya dari biaya sewa yang dipungut bukan tambahan berupa bunga atau sewa modal yang diperhitungkan dari uang pinjaman.
\end{abstract}

Kata Kunci: Gadai, Islam, Rahn.

\section{DASAR PEMIKIRAN}

\section{Latar Belakang}

Lembaga keuangan non bank adalah semua badan yang melakukan kegiatan dibidang keuangan, yang secara langsung atau tidak langsung menghimpun dana terutama dengan jalan mengeluarkan kertas berharga dan menyalurkan dalam masyarakat terutama guna membiayai investasi perusahaan. Atau dapat juga diartikan sebagai badan usaha yang melalukan kegiatan dibidang keuangan, secara langsung ataupun tidak langsung, menghimpun dana dari masyarakat dan menyalurkan kembali kepada masyarakat untuk kegiatan produktif.

Manfaat dari lembaga keuangan bukan bank ini adalah membantu menggerakkan sistem perekonomian masyarakat, khususnya melayani kebutuhan ekonomi masyarakat yang tidak bisa dijangkau oleh fungsi lembaga perbankan. Hal ini dikaitkan dengan masalah psikologis yang dimiliki oleh sebagian masyarakat, dimana ada kelompok yang 
masih memandang lembaga perbankan sebagai lembaga eksklusif, sehingga kelompok ini merasa segan dan enggan berurusan dengan lembaga tersebut. Orang-orang dari kelompok ini, merasa enggan berhubungan dengan lembaga perbankan karena dianggap rumit dan sistem yang harus dijalankan sangat sulit. Oleh karena itu, seringkali orangorang dari kalangan ini lebih memilih lembaga keuangan bukan bank ketika mereka membutuhkan bantuan finansial. Sebab, lembaga-lembaga ini dianggap lebih sesuai dengan budaya dan karakter mereka, serta lebih mengedepankan pendekatan non formal. Lembaga keuangan non bank tetap menjalankan peran intermediasi keuangan yaitu, mengelola dana dari pihak yang memiliki kelebihan dana, untuk disalurkan kepada pihak yang lebih membutuhkan suntikan dana.

Dalam kehidupan sehari-hari manusia tidak lepas dengan transaksi, Allah SWT telah menjadikan manusia saling melengkapi antara satu dengan yang lainnya, agar mereka saling tolong-menolong, baik dengan jalan tukar-menukar, sewa menyewa, bercocok tanam atau dengan cara yang lainnya, karena sejatinya manusia adalah makhluk sosial (social creature). Bentuk dari tolong menolong ini bisa berupa pemberian dan bisa berupa pinjaman (gadai). (Hadi, 2003:2) Belum banyaknya masyarakat yang mengetahui gadai syariah dan guna mengetahui gadai dalam Islam lebih jauh penulis tertatarik menulis gadai dalam Islam.

Penelitian ini merupakan penelitian jenis pustaka (library research) yang menitikberatkan pada pengelolaan data secara kualitatif dengan metode analisis data menggunakan metode deskriptif-analisis. Penelitian ini bertujuan untuk menggambarkan atau membeberkan pa yang terjadi sekarang (Arikunto, 2002:9), dan mengeksplorasi penomena-penomena yang tidak dapat dikuantifikasikan (Satori dan Komariah, 2009:23). Selain itu, deskriptif penting karena merupakan metode analisis data yang berfungsi untuk menjelaskan suatu pikiran (fakta) sehingga dapat diterima secara rasional (Surabaya, 2007:18).

\section{Tinjauan Pustaka}

Ayu Afifah dalam Tinjauan Hukum Islam Tentang Praktik Gadai Barang Rumah Tangga (Studi Kasus di Masyarakat Talang Kec. Teluk Betung Selatan, Bandar Lampung) 2019 mengemukakan bahwa pelaksanaan praktik gadai barang rumah tangga 
Ekonomica Sharia: Jurnal Pemikiran dan Pengembangan Ekonomi Syariah Volume 6 Nomor 1 Edisi Agustus 2020 | 63

yang di lakukan oleh masyarakat yaitu dengan melakukan perjanjian gadai dimana jaminannya berupa barang rumah tangga. Apabila jatuh tempo yang telah ditentukan Rahin belum sanggup membayar, maka Murtahin meminta Rahin untuk menjual barang rumah tangga kepada pihak lain, bilamana terdapat kelebihan harga barang jaminan melebihi jumlah hutang, Rahin meminta untuk di bagi dua. Adapun pelaksanaan praktik gadai barang rumah tangga ini tidak sesuai dengan Hukum Islam, di karenakan telah merugikan salah satu pihak yaitu pihak Murtahin.

Imron Saifudin dalam Penyelesaian gadai berakhir jual beli menurut perspektif hukum Islam (Studi Kasus Di Desa Indraloka 1 Kecamatan Way Kenanga Kabupaten Tulang Bawang Barat) meneliti hukum jual beli. Berdasarkan hasil penelitian, bahwa pihak Rahin tidak bisa mengembalikan hutang yang ia terima kemudian Murtahin memaksa Rahin untuk menjual barang jaminan dengan harga yang Murtahin tentukan, pada saat jatuh tempo Murtahin telah memberi waktu untuk mengembalikan hutangnya, namun Rahin tetap tidak bisa mengembalikan hutangnya, kemudiann Murtahin memaksa Rahin untuk menjual barang yang dijaminkan dengan harga yang ditentukan Murtahin. Menurut hukum Islam jual beli yang pada awal akad gadai belum sesuai menurut aturan hukum Islam, karena pemaksaan terjadinya jual beli dan penentuan harga sepihak, hal tersebut merugikan pihak Rahin karena harga yang tidak sesuai dengan harga pada umumnya

\section{PEMBAHASAN}

\section{A. Pengertian pegadaian}

Pegadaian adalah suatu lembaga keuangan bukan bank yang memberikan kredit kepada masyarakat dengan corak khusus, yaitu secara hukum gadai. Pengertian hukum gadai adalah kewajiban calon peminjam untuk menyerahkan harta geraknya (sebagai agunan) kepada kantor cabang pegadaian, disertai dengan pemberian hak kepada pegadaian untuk melakukan penjualan (lelang) misalnya perhiasan, barang elektonika, sepeda motor, kain, dan sebagainya. (Subagyo.1998: 88-89).

Selanjutnya, pengertian pelelangan adalah penjualan barang agunan oleh perusahaan pegadaian apabila setelah batas waktu perjanjian kredit habis, nasabah tidak menebus barang tersebut, atau tidak memperpanjang kredit. Satu-satunya perusahaan 


\section{4}

Choirunnisak, Disfa Lidian Handayani, Gadai dalam Islam...•

pegadaian di Indonesia saat ini adalah perusahaan milik pemerintah (BUMN), yang berada dibawah wewenang departemen keuangan. Badan usaha ini berstatus perusahaan umum (perum) dengan nama perum pegadaian. Kegiatan usaha perum pegadaian tersebut diatur oleh peraturan pemerintsh Nomor 10 Tahun 1990. usaha perum pegadaian ini terutama adalah memberi kredit gadai pada masyarakat dengan prosedur yang sederhana dan cepat, ditambah dengan kegiatan lain yang masih erat kaitannya dengan usaha gadai.

Secara umum pengertian usaha gadai adalah kegiatan menjaminkan barang-barang berharga kepada pihak-pihak tertentu, guna memperoleh sejumlah uang dan barang yang dijaminkan akan ditebus kembali sesuai dengan perjanjian antara nasabah dengan lembaga gadai.

Dan dari pengertian diatas dapat disimpulkan bahwa usaha gadai memiliki ciri-ciri sebagai berikut: (Subagyo.1998: 88-89)

1. Terdapat barang-barang berharga yang digadaikan.

2. Nilai jumlah pinjaman tergantung nilai barang yang digadaikan.

3. Barang yang digadaikan dapat ditebus kembali

\section{B. Asal Mula Pegadaian}

Lembaga kredit dengan sistem gadai sudah ada di bumi indonesia sejak masa VOC. Ada pun institusi yang menyelenggarakan usaha ini pada waktu itu disebut bank van leening. Usaha ini semula dilakukan oeleh swasta, dan setelah melalui proses waktu yang panjang, kemudian diambil alih dan dimonopoli oleh pemerintah. Pegadaian negeri pertama kali di dirikan pada tanggal 1 April 1901 di Sukabumi (jawa barat) melalui ordonasi yang diterbitkan dengan Staadsblad Nomor 131. Tanggal tersebut selanjutnya dijadikan tanggal kelahiran pegadaian di indonesia. Munculnya rumahrumah gadai di beberapa tempat di indonesia di sebabkan adanya berbagai Staadsblad lain seperti: (Subagyo.1998: 88-89)

1. Staadsblad Nomor 402 tahun 1903, staadsblad Nomor 28 tahun 1921, dan berbagai staadsblad untuk mendirikan rumah-rumah gadai dijawa dan madura.

2. Staadsblad Nomor 420 tahun 1921 mengatur rumah gadai disumatera barat. 
Ekonomica Sharia: Jurnal Pemikiran dan Pengembangan Ekonomi Syariah Volume 6 Nomor 1 Edisi Agustus $2020 \mid 65$

Status hukum ini semula jawatan, kemudian pada tahun 1961 berubah menjadi perusahaan negara (PN) pegadaian, dan tahun 1969 diubah lagi menjadi perusahaan pemerintah Nomor 10 tqhun 1990, status hukum pegadaian ditingkatkan menjadi perusaahan umum (perum). Dalam sejarah dunia usaha pegadaian pertama kali dilakukan di italia. Kemudian dalam perkembangan selanjutnya meluas ke wilayahwilayah eropa lainnya seperti inggris, prancis dan belanda. Oleh orang-prang belanda lewat pihak VOC usaha pegadaian dibawa masuk ke hindia belanda.

Sejak pegadaian negara pertama kali diresmikan pada 01 april 1901 di sukabumi, perusahaan ini terus menunjukkan perkembangan yang baik. Posisinya yang strategis dengan usaha inti berupa jasa gadai mampu memberikan makna bagi pemberdayaan ekonomi dan kesejahteraan masyarakat indonesia. Jargonnya yang dikenal dengan "mengatasi masalah tanpa masalah" telah memberikan bukti yang kuat atas kesusksesan lembaga keuangan ini.

\section{Sumber Dana dan Penggunaan Dana}

Dalam menjalankan aktivitasnya, perum pegadaian harus memiliki sumber dana terlebih dahulu. Kemudian setelah terhimpun, dana itu harus disalurkan ke aktiva produktif tertentu agar dapat memberikan keuntungan bagi perum pengadaian. Secara umum, sumber dana dan penggunaan dana perum pegadaian adalah sebagai berikut: (Arthesa, Handiman. 2006: 274-275)

1. Sumber dana

Sumber dana pada perum pegadaian berasal dari:

a. Modal sendiri, modal sendiri yang dimiliki oleh perum pegadaian berasal dari modal awal, penyertaan dari pemerintah, dan laba ditahan yang berasal dari akumulasi laba sejak masa pemerintahan hindia belanda.

b. Pinjaman jangka pendek, pinjaman jangka pendek berasal dari perbankan dan pihak lainnya. Pinjaman dari perbankan merupakan sumber dana yang paling dominan dibandingkan dengan sumber dana lainnya. Adapun pinjaman dari pihak lainnya berasal dari pendapatan diterima dimuka, biaya yang masih harus dibayar, dan lainnya. 
66 Choirunnisak, Disfa Lidian Handayani, Gadai dalam Islam....

c. Penerbitan obligasi, obligasi atau instrumen surat hutang diterbitkan dengan tujuan menghimpun dana dari masyarakat. Atas obligasi yang dibelinya, masyarakat memperoleh imbalan berupa bunga.

2. Penggunaan dana

Penggunaan dana pada perum pegadaian adalah untuk hal-hal sebagai berikut:

a. Uang kas,

Uang kas merupakan dana likuid yang harus selalu tersedia untuk memenhi kewajiban yang harus segera dibayar. Kewajiban ini berupa pengeluaran untuk jasa pembiayaan, biaya pajak, biaya operasional, dan biaya-biaya lainnya.

b. Jasa pembiayaan, jasa pembiayaan merupakan aktivitas utama perum pegadaian yang akan memberikan pendapatan yang paling dominan. Penggunaan dana terbesar diperum pegadaian adalah untuk aktivitas ini. Pendapatan yang diterima adalah berupa bunga dan biaya administratif lainnya.

c. Operasional perusahaan, kegiatan operasional perusahaan pada perum pegadaian adalah berupa pembayaran upah penggawai, perawatan barang bergerak, dan lainnya.

d. Pembelian aktiva tetap, pembelian aktiva tetap ditunjukkan untuk menunjang aktivitas usaha dari perum pegadaian. Aktiva tetap umumnya berupa kantor, gudang penyimpanan barang, peralatan, kendaraan, dan lainnya.

e. Investasi, investasi dilakukan pada dana-dana yang tidak dapat tersalurkan kemasyarakat. Kelebihan dana ini belum diperlukan oleh masyarakat dalam jangka pendek, sehingga perum pegadaian memanfaatkannya untuk pembelian instrumen investasi jangka pendek yang diharapkan dapat memberikan keuntungan.

\section{Barang Jaminan}

Bagi nasabah yang ingin memperoleh fasilitas pinjaman dari perum pegadaian, maka hal yang paling penting diketahui adalah masalah barang yang dapat menjadi jaminan. Pada dasarnya barang apapun yang bisa dijual maka bisa dijadikan sebagai barang gadai. (Hussain, Muhbubi. 2017: 197) 
Ekonomica Sharia: Jurnal Pemikiran dan Pengembangan Ekonomi Syariah Volume 6 Nomor 1 Edisi Agustus 2020 | 67

Perum pegadaian dalam hal jaminan telah menetapkan ada beberapa jenis barang berharga yang dapat diterima untuk digadaikan. Barang-barang tersebut nantinya akan ditaksir nilainya, sehingga dapatlah diketahui berapa nilai taksiran dari barang yang digadaikan. Besarnya jaminan diperoleh dari 80 hingga 90 persen dari nilai taksiran. Semakin besar nilai taksiran barang, semakin besar pula pinjaman yang diperoleh. (Kasmir. 2017: 234-237).

Jenis-jenis barang berharga yang dapat diterima dan dapat dijadikan jaminan oleh perum pegadaian sebagai berikut:

1. Barang-barang atau benda-benda perhiasan antara lain:
a. Emas
b. Perak
c. Intan
d. Berlian
e. Mutiara
f. Platina

2. Barang-barang berupa kendaraan:
a. Mobil (termasuk bajaj dan bemo)
b. Sepeda motor
c. Sepeda biasa (termasuk becak)

3. Barang-barang elektronik antara lain:
a. Televisi
b. Radio
c. Radio tape
d. Video
e. Komputer
f. Kulkas
g. Tustel
h. Mesin tik

4. Mesin-mesin seperti:
a. Mesin jahit
b. Mesin kapal motor 
68

Choirunnisak, Disfa Lidian Handayani, Gadai dalam Islam....

5. Barang-barang keperluan rumah tangga seperti:

a. Barang tekstil, berupa pakaian, permadani atau kain batik.

b. Barang-barang pecah belah dengan catatan bahwa semua barang- barang yang dijaminkan haruslah dalam kondisi baik dalam arti masih dapat digunakan atau bernilai. Hal ini bagi pegadai penting mengingat apabila nasabah tidak dapat mengembalikan pinjamannya, maka barang jaminan akan dilelang sebagai penggantinya.

\section{E. Keuntungan Usaha Gadai}

Tujuan utama usaha pegadaian adalah untuk mengatasi agar masyarakat yang sedang membutuhkan uang tidak jatuh ketangan para pelepas uang atau tukang ijon atau tukang rentenir yang bunganya relatif tinggi. Perusahaan pegadaian menyediakan pinjaman uang dengan jaminan barang-barang berharga. Meminjam uang keprum pegadaian bukan saja karena prosedurnya yang cepat dan mudah, tetapi karena biaya yang dibebankan lebih ringan jika dibandingkan dengan para pelepas uang atau tukang ijon. Hal ini dilakukan sesuai dengan salah satu tujuan dari perum pegadaian dalam memberi pinjaman kepada masyarakat dengan moto "menyelesaikan masalah tanpa masalah".

Jika seseorang membutuhkan dana sebenarnya dapat diajukan ke berbagai sumber dana, seperti meminjam uang ke bank atau lembaga keuangan lainnya. Akan tetapi, kendala utamanya adalah prossedurnya yang rumit dan memakan waktu yang relatif lebih lama. Kemudian disamping itu, persyaratan yang lebih sulit untuk dipenuhi adalah seperti dokumen yang harus lengkap, membuat masyarakat mengalami kesulitan untuk memenuhinya. Begitu pula dengan jaminan yang diberikan harus barang-barang tertentu, karena tidak semua barang dapat dijadikan jaminan bank.

Namun diperusahaan pegadaian begitu mudah dilakukan, masyarakat cukup datang kekantor pegadaian terdekat dengan membawa jaminan barang tertentu, maka uang pinjaman pun dalam wakti singkat dapat terpenuhi. Jaminannya pun sangat sederhana sebagai contoh adalah jaminan dengan jam tangan saja sudah cukup untuk memperoleh sejumlah uang dan hal ini hampir mustahil dapat dilakukan dilembaga keuangan lainnya. 
Ekonomica Sharia: Jurnal Pemikiran dan Pengembangan Ekonomi Syariah Volume 6 Nomor 1 Edisi Agustus 2020 |69

Keuntungan lain dipegadaian adalah piak pegadaian tidak mempermasalahkan untuk apa uang tersebut digunakan dalam hal ini tentu bertolak belakang dengan pihak perbankan yang harus dibuat serinci mungkin tentang peguanaan uangnya. Begitu pula dengan sanksi yang diberikan relatif ringan, apabila tidak bisa melunasi dalam waktu tertentu. Sanksi yang paling berat adalah jaminan yang disimpan akan dilelang untuk menutupi kekurangan pinjaman yang telah diberikan.

Jadi keuntungan perusahaan pegadaian jika dibandingkan dengan lembaga keungan bank atau lembaga keuangan lainnya adalah:

1. Waktu yang relatif singkat untuk memperoleh uang, yaitu pada hari itu juga, hal ini disebabkan oleh prosedurnya yang tidak berbelit-belit.

2. Persyaratan yang sangat sederhana sehingga memudahkan konsumen untuk memenuhinya.

3. Pihak pegadaian tidak mempermasalahkan uang tersebut digunakan untuk apa, jadi sesuai dengan kehendak nasabahnya.

\section{F. Prosedur Pinjaman}

Seperti diketahui bahwa menariknya peminjaman uang dipegadaian disebabkan prosedurnya yang mudah, cepat dan biaya yang dikenakan relatif ringan. Disamping itu, biasanya perum pegadaian tidak begitu memintingkan untuk apa uang tersebut digunakan. Yang penting setiap proses peminjaman uang dipegadaian haruslah dengan jaminan barang-barang tertentu. Hal ini tentu sangat berlawanan dengan prosedur peminjaman dilembaga keuangan lainnya seperti bank.

Secara garis besar proses atau prosedur peminjaman uang diperum pegadaian dapat dijelaskan berikut ini:

1. Nasabah datang langsung kebagian informasi untuk memperoleh penjelasan, tentang pegadaian, misalnya tentang barang jaminan, jangka waktu pengambilan, jumlah pinjaman, dan biaya sewa modal (bunga pinjaman)

2. Bagi nasabah yang sudah jelas dan mengetahui prosedurnya dapat langsung membawa barang jaminan dibagian penaksir untuk menaksir nilai jaminan yang diberikan. Pemberian barang jaminan disertai bukti diri seperti KTP atau surat kuasa bagi pemilik barang yang tidak dapat datang. 
$\mathbf{7 0}$ Choirunnisak, Disfa Lidian Handayani, Gadai dalam Islam....

3. Bagian penaksir akan menaksir nilai jaminan yang diberikan, baik kualitas barang maupun nilai barang tersebut, kemudian barulah ditetapkan nilai taksir barang tersebut.

4. Setelah nilai taksir ditetapkan langkah selanjutnya adalah menentukan jumlah pinjaman beserta sewa modal (bunga) yang dikenakan dan kemudian diinformasikan kecalon peminjam.

5. Jika calon peminjam setuju, maka barang jaminan ditahan untuk disimoan dan nasabah memperoleh pinjaman, berikut surat bukti gadai.

Kemudian untuk proses pembayaran kembali pinjaman baik yang sudah jatuh tempo maupun yang belum dapat dilakukan sebagai berikut.

1. Pembayaran kembali pinjaman berikut sewa modal dapat langsung dilakukan dikasir dengan menunjukan surat bukti gadai dan melakukan pembayaran sejumlah uang.

2. Pihak pegadai menyerahkan barang jaminan apabila pembayarannya sudah lunas dan diserahkan langsung ke nasabah untuk diperiksa kebenarannya dan jika sudah benar dapat langsung dibawa pulang.

3. Pada prinsipnya pembayaran kembali pinjaman dan sewa modal dapat dilakukan sebelum jangka waktu pinjaman jatuh tempo. Jadi si nasabah jika sudah punya uang dapat langsung menebus jaminannya.

4. Bagi nasabah yang tidak dapat membayar pinjamannya, maka barang jaminannya akan dilelang secara resmi ke masyarakat laus.

5. Hasil penjualan lelang diberitahukan kepada nasabah dan seandainya uang hasil lelang setelah dikurangi pinjaman dan biaya-biaya masih lebih akan dikembalikan ke nasabah.

\section{G. Produk Dan Jasa Sistem Konvensional Dan Syariah}

a. Produk dan jasa sistem konvensional

1. Jasa taksiran

Layanan pegadaian untuk memberikan penilaian berbagai jenis dan kualitas emas dan berlian, para penaksir akan bergerak atau bertindak sesuai dengan ketentuan yang berlaku. (Suhendi .2018:215-218) 
Ekonomica Sharia: Jurnal Pemikiran dan Pengembangan Ekonomi Syariah Volume 6 Nomor 1 Edisi Agustus $2020 \mid 71$

\section{Jasa titipan}

Bagi nasabah yang ingin menyimpan barangnya yang berharga, dapat menyimpan dipegadaian dengan layanan titipan, dengan prosedur mudah, layanan murah, dan barang akan dijamin oleh pegadaian. Selain itu, jika nasabah akan meninggalkan rumah dalam jangka waktu yang lama, nasabah dapat menitipkan barang-barang dipegadaian.

\section{Penjualan koin emas $\mathrm{ONH}$}

Koin emas ONH adalah emas yang berbentuk koin yang dapat dogunakan untuk tujuan persiapan dana pergi menunaikan ibada haji bagi pembelinya. Nasabah hanya cukup untuk membeli sejumlah koin $\mathrm{ONH}$ (yang tersedia dalam pilihan berat), baik sekali saja maupun rutin. Setelah koin emas ONH milik nasabah telah mencapai sekitar 250-300 gram, secara otomatis nasabah akan didaftarkan sebagai calon jamaah haji melalui sistem haji terpadu (siskoat). selain untuk haji, dapat pula dibeli untuk tujuan investasi.

4. unit tokoh emas "galeri 24"

5. Krasida

Kredit angsuran sistem gadai merupakan pemberian pinjaman kepada para pengusaha mikro kecil (dalam rangka mengembangkan usaha) atas dasar gadai yang pengembalian pinjamannya dilakukan melalui angsuran.dengan jangka waktu maksimal tigatahun dan jaminan bergerak, seperti: perhiasan, kendaraan bermotor, dan barang bergerak lainnya.

\section{Kreasi}

Kreasi adalah pemberian pinjaman uang yang ditunjukkan kepada pengusaha kecil dengan menggunakan konstruksi penjaminan kredit atas dasar fidusia. Kredit atas dasar fidusia merupakan pengikatan jaminan dengan lembaga pengikatan jaminan yang sempurna dan memberi hak yang preferent kepada kreditor, dalam hal ini adalah lembaga jamin atau fidusia. kredit pada fitur fidusia, bagi kreditor dan debitur merupakan jaminan yang ideal. 
b. Produk dan jasa gadai syariah

1. Pengertian

Al-Rahn dalam kamus bahasa arab menggadaikan, menangguhkan atau jaminan hutang, gadaian. (Bisri, dkk. 1999: 274) Dan dapat juga dimaknai dengan alhabsu. Secara etimologi rahn (gadaian) berarti tetap atau lestari, sedangkan al-habsu berarti penahanan. (Pasaribu. 1996: 139) Begitupun jika dikatakan "ni"matun rohinah" artinya: karunia yang tetap dan lestari. (Sabiq. 1996: 139). Menurut syarak kalimat Rahn itu artinya menjadikan harta sebagai pengkukuh/penguat sebab adanya hutang. (Bakar. 1995: 584). Rahn dalam pengertian hukum perdata adalah sama dengan gadai, tetapi dalam pengertian syariah terdapat hal-hal spesifik yang tidak terdapat pada pengertian gadai, yaitu sebagai berikut:

a) Rahn artinya tetap, kekal, dan jaminan. Menurut beberapa mazhab, rahn berarti perjanjian penyerahan harta yang oleh pemiliknya dijadikan jaminan utang yang nantinya dapat dijadikan sebagai pembayaran hak piutang tersebut, baik seluruhnya maupun sebagian.

b) Rahn adalah produk jasa berupa pemberian pinjaman menggunakan sistem gadai dengan berlandaskan prinsip-prinsip syariat Islam, dimana tidak menentukan tarif jasa dari besarnya uang pinjaman.

c) Rahn dalam hukum Islam dilakukan secara sukarela atas dasar tolong menolong tidak untuk semata mencari keuntungan.

2. Landasan hukum pengadaian syariah

Di riwayatkan oleh ahmad, bukhari, nasai, dan ibnu majah dari anas r.a ia berkata: "rasulullah saw. Menrungguhkan baju besi kepada seorang yahudi di madinah ketika beliau mengutangkangandum dari seorang yahudi" dari hadist diatas, dapat dipahami bahwa agama islam tidak membeda-bedakan antara orang muslim dan non-muslim dalam bidang muamalah, maka seorang muslim tetap wajib membayar hutangnya sekalipun kepada non muslim.

3. Mekanisme operasional pegadaian islam

Dari landasan islam tersebut, maka mekanisme operasinal pegadaian islam dapat digambarkan sebagai berikut; melalui akad rahn, nasabah menyerahkan barang bergerak dan kemudian pegadaian menyimpan dan merawatnya ditempat yang telah disediakan 
Ekonomica Sharia: Jurnal Pemikiran dan Pengembangan Ekonomi Syariah Volume 6 Nomor 1 Edisi Agustus $2020 \mid 73$

oleh pegadaian. Akibat yang timbul dari proses penyimpanan adalah timbulnya biayabiaya yang meliputi nilai investasi tempat penyimpanan, biaya perawatan, dan keseluruhan proses kegiatannya. Atas dasar ini dibenarkan bagi pegadaian mengenakan biaya sewa kepada nasabah sesuai jumlah yang disepakati oleh kedua belah pihak.

Pegadaian islam akan memperoleh keuntungan hanya dari biaya sewa yang dipungut bukan tambahan berupa bunga atau sewa modal yang diperhitungkan dari uang pinjaman. Sehingga disini dapat dikatakan proses pinjam meminjam uang hanya sebagai "lipstick" yang akan menarik minat konsumen untuk menyimpan barangnya dipegadaian.

Adapun ketentuan atas persyaratan yang menyertai akad tersebut meliputi:

a. Akad, akad tidak mengandung syarat fasik/batil seperti murtahil mensyaratkan barang jaminan dapat di manfaatkan tanpa batas.

b. Marhun bih (pinjaman), pinjaman merupakan hak yang wajib dikembalikan kepada murtahin dan bisa dilunasi dengan barang yang di rahn kan tersebut. Serta pinjaman itu jelas dan tertentu.

c. Marhun (barang yang di rahn kan), marhun bisa dijual dan nilainya seimbang dengan pinjaman, memiliki nilai, jelas ukurannya, milik sah penuh dari rahin, tidak terkait dengan hak orang lain, dan bisa diserahkan baik materi maupun manfaatnya.

d. Jumlah maksimum dana rahn dan nilai likuidasi barang yang di rahn kan serta jangka waktu rahn di tetapkan dalam prosedur.

e. Rahin dibebani oleh jasa manajemen atas barang berupa biaya asuransi, keamanan, dan pengolahan serta administrasi.

\section{H. Perbedaan Pegadaian Konvensional Dan Syariah}

1. Pegadaian konvensional

a. Didasarkan pada peraturan pemerintah nomor 103 tahun 2000

b. Biaya administrasiberdasarkan persentase dan golongan barang

c. Bila lama pengembalian pinjaman lebih dari perjanjian barang gadai dilelang kepada masyarakat ( Soemitra. 2009: 81)

d. Sewa modal dihitung dengan: persentase $\mathrm{x}$ uang pinjaman(UP)

e. Maksimal jangka waktu 4 bulan. 
74 | Choirunnisak, Disfa Lidian Handayani, Gadai dalam Islam....

f. Uang kelebihan(UK)-(uang pinjaman+sewa modal+biaya lelang).

g. Bila dalam satu tahun uang kelebihan tidak diambil, uang kelebihan tersebut menjadi milik pegadaian.

h. 1 hari dihitung 15 hari

i. Mengenakan bunga (sewa modal) terhadap nasabah uang memperoleh pinjaman.

j. Istilah-istilah yang digunakan: gadai, pegadaian, nasabah, barang pinjaman, dan pinjaman.

2. Pegadaian syariah

a. Didasarkan pada peraturan pemerintah nomor 103 tahun 2000 dan hukum agama Islam.

b. Biaya administrasi menurut ketetapan berdasarkan golongan barang.

c. Bilamana lama pengembalian pinjaman lebih dari akad, barang gadai nasabah dijual kepada masyarakat.

d. Jasa simpanan dihitung dengan konstanta $\mathrm{x}$ taksiran

e. Maksimal jangka waktu 3 bulan.

f. Uang kelebihan(UK) = hasil penjualan-(uang pinjaman+jasa penitipan+biaya penjualan).

g. Bila dalam satu tahun uang kelebihan tidak diambil, diserahkan kepada lembaga ZIS.

h. 1 hari dihitung 5hari

i. Tidak mengenakan bunga kepada nasabah yang mendapatkan pinjaman

j. Istilah-istilah yang digunakan: rahn, murtahin, rahin, marhun, dan marhun bih.

\section{SIMPULAN}

Gadai dalam Islam disebut Rahn. Pegadaian Islam akan memperoleh keuntungan hanya dari biaya sewa yang dipungut bukan tambahan berupa bunga atau sewa modal yang diperhitungkan dari uang pinjaman. 


\section{DAFTAR PUSTAKA}

Arikunto, Suharsimi prosedur penelitan: suatu pensekatan praktek: Jakarta Rineka Cipta. 2002

Arthesa, Ade, \& Handiman, Edia, bank dan lembaga keuangan bukan bank, Jakarta: indeks 2006.

Bisri, Adib, dan AF, Munawir, Kamus AL-BISRI, Surabaya: Pustaka Progressif, 1999.

Hadi, Subagyo, bank dan lembaga keuangan lainnya, Yogyakarta: Sekolah Tinggi Ekonomi YKPN 1998

Kasmir, bank dan lembaga keuangan lainnya, Jakarta: Rajawali Pers, 2017.

Pasaribu, Choiruman dan K, Suhrawardi. Lubis, Hukum Perjanjian Dalam Islam, Jakarta: Sinar Grafika, 1996.

Sayyid Sabiq, Fikih Sunnah, Alih bahasa. H. Kamaluddin A Marjuki, (Bandung: PT. Al- Maarif, 1996.

Soemitra, Andri, Bank Dan Lembaga Keuangan Islam, Jakarta: Kencana Media Group, 2009.

Sotari, Djam dan aan Komariah, Metodologi Penelitian Kualitatif, Bandung: PT. Alfabeta. 2009.

Suhendi, Hendi, fiqih muamalah, Jakarta: PT. RajaGrafindo Persada, 2008.

Taqiyuddin Abu Bakar, Kifayatul Akhyar Fii Halli Ghayatil Ikhtishar, alih bahasa oleh Syarifuddin Anwar, Mishbah Musthafa, Surabaya: Bina Iman, 1995.

\section{Jurnal}

Lokmanulhakim Hussain dan Mohammad Mahbubi Ali, Sharī ah non-compliant assets as rahn (pledge) in Islamic banking products: a fiqhī perspective, ISRA International Journal of Islamic Finance Vol. 9 No. 2, (2017.

\section{Skripsi}

Ayu Afifah.Tinjauan Hukum Islam Tentang Praktik Gadai Barang Rumah Tangga

(Studi Kasus di Masyarakat Talang Kec. Teluk Betung Selatan, Bandar Lampung) 2019. Jurusan Muamalah Fakultas Syariah 2019.

Imron Saifudin. Penyelesaian gadai berakhir jual beli menurut perspektif hukum Islam (Studi Kasus Di Desa Indraloka 1 Kecamatan Way Kenanga Kabupaten Tulang Bawang Barat). Jurusan Hukum Syariah, Fakultas Syariah, IAIN Metro 2017 
76 | Choirunnisak, Disfa Lidian Handayani, Gadai dalam Islam.... 